\title{
Slide Pharyngo-Esophagostomy Following Ablation of Hypopharyngeal Cancer
}

\author{
Ming-Ho Wu*, Han-Yun Wu \\ Department of Surgery, Tainan Municipal Hospital, Taiwan \\ Email: ^m2201@mail.ncku.edu.tw
}

How to cite this paper: $\mathrm{Wu}, \mathrm{M} .-\mathrm{H}$. and $\mathrm{Wu}$, H.-Y. (2017) Slide Pharyngo-Esophagostomy Following Ablation of Hypopharyngeal Cancer. Surgical Science, 8, 403-406. https://doi.org/10.4236/ss.2017.89043

Received: August 10, 2017

Accepted: September 2, 2017

Published: September 5, 2017

Copyright $\odot 2017$ by authors and Scientific Research Publishing Inc. This work is licensed under the Creative Commons Attribution International License (CC BY 4.0).

http://creativecommons.org/licenses/by/4.0/

\begin{abstract}
We describe a procedure of slide pharyngo-esophagoplasty for restoration following ablation of hypopharyngeal cancer in a 99 year-old man. The elderly presented to our hospital with 2-month dysphagia, occasional bloody salivation, and 2-day respiratory distress. To solve the problems of swallowing difficulty and dyspnea, he underwent laryngopharyngectomy, permanent tracheostomy, and slide pharyngo-esophagoplasty. The patient was uneventful after the restoration procedure.
\end{abstract}

\section{Keywords}

Hypopharyngeal Cancer, Laryngopharyngectomy, Slide Pharyngo-Esophagoplasty

\section{Introduction}

Common restoration procedures following ablation of hypopharyngeal cancer are pectoralis major myocutaneous flap, radial forearm free flap, free jejunal flap, gastric pull-up reconstruction, ileocolon pull-up reconstruction, and laryngotracheal flap [1] [2] [3]. These procedures usually require a long operation time and some of them require microscopic vascular anastomosis. Herein, we report a simple procedure of slide pharyngo-esophagostomy to restore the pharyngeal defect after ablation of hypopharyngeal cancer.

\section{Case Presentation}

A 99 year-old man had history of diabetes mellitus and pulmonary tuberculosis. He suffered from dysphagia for more than 2 months with occasional bloody salivation. Endoscopy showed an $8 \mathrm{~cm} \times 6 \mathrm{~cm}$ mass in the hypopharynx (Figure 1 ), and computed tomography revealed the larynx was invaded by the hypopha- 


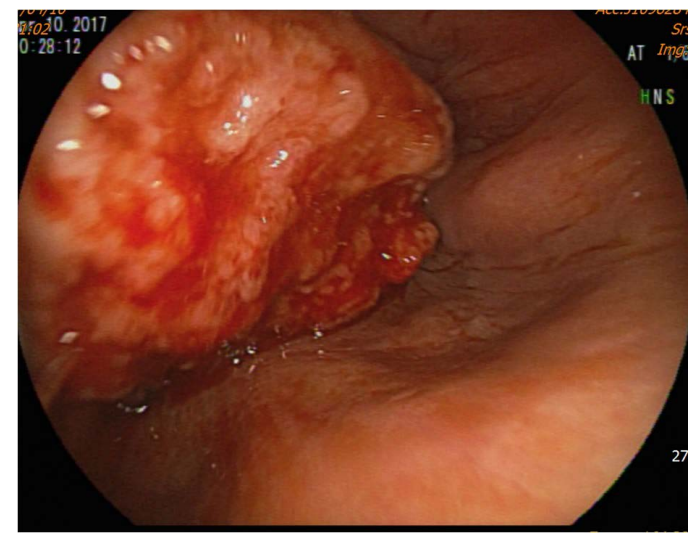

Figure 1. Endoscopy showed an $8 \mathrm{~cm} \times 6 \mathrm{~cm}$ mass in the hypopharynx.

ryngeal cancer (Figure 2). The elderly presented with 2-day respiratory distress before surgery. He underwent laryngopharyngectomy, permanent tracheostomy, and slide pharyngo-esophagoplasty following ablation of the hypopharyngeal cancer. A near circumferential defect was observed at the anterior pharyngeal wall. The slide pharyngo-esophagoplasty consisted of pull-up of esophagus around $8 \mathrm{~cm}$ after dissection at the cervicothoracic region, posterior split of the proximal esophagus, and direct pharyngoesophageal anastomosis (Figure 3). Total operation time including a feeding gastrostomy was 4 hours and $45 \mathrm{mi}$ nutes. The nasogastric tube was removed on postoperative day 2 . He was allowed oral intake on post-op day 9 and was very well in a 5-month follow-up.

\section{Comments}

A circumferential or near circumferential defect usually present following ablation of hypopharyngeal cancer that requires a suitable procedure to accomplish the restoration. A large circumferential defect of pharynx required more tissue to repair. In a review article, reconstructive options include pectoralis major myocutaneous flap, gastric pull-up, pedicled latissimus dorsi myocutaneous flap, thoracodorsal artery perforator flap, supraclavicular flap, ileocolon flap, gastro-omental free flap, colon interposition, and sternocleidomastoid myocutaneous flap, etc. [4]. These above reconstructive procedures usually require a long operating time. Postoperative complication includes graft failure, fistula, or anastomotic stricture [1] [2] [3] [4]. According to our previous experimental study, a long esophageal stump could be viable after mobilization [5]. Meanwhile we have performed a slide pharyngo-esophagostomy in a patient with corrosive stricture at the esophageal orifice [6]. In the presented 99-year elderly, endoscopy showed tumor obstruction at the hypopharynx and computed tomography revealed laryngeal compression by the hypopharyngeal carcinoma. The patient's ECOG performance status was grade-3. Preoperative considerations included the old age, the patient's performance, and a total operating time. Hence, to solve the patient's problems of dysphagia and dyspnea, an urgent simple sur- 


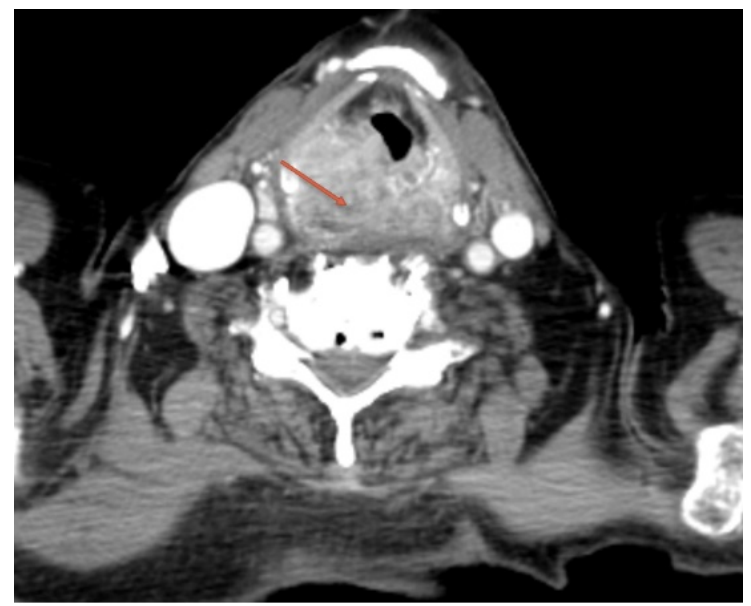

Figure 2. Computed tomography revealed the larynx was invaded by the hypopharyngeal cancer (arrow).

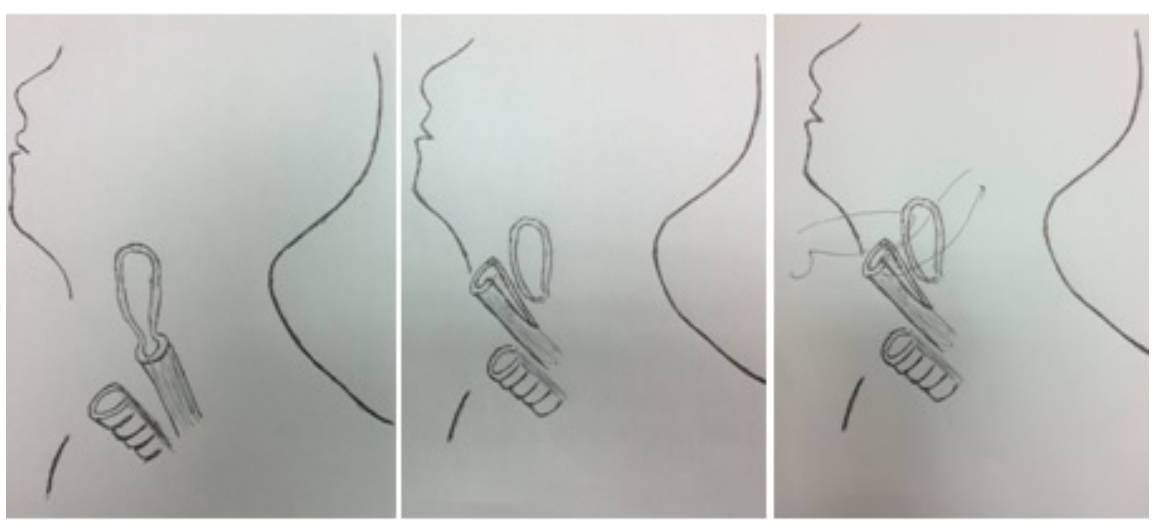

Figure 3. A near circumferential defeat presented following ablation of hypopharyngeal cancer (left), pull-up of esophagus around $8 \mathrm{~cm}$ and posterior split of the proximal esophagus (middle), and direct pharyngoesophageal anastomosis (right).

gical intervention was needed. We favor the slide pharyngo-esophagostomy to repair the near circumferential pharyngeal defect because it is simple and needs a shorter operation time.

\section{Disclosure}

The authors declare no conflict of interest.

Informed consent was obtained from the patient to report the case.

\section{References}

[1] Van der Putten, L., Spasiano, R., de Bree, R., Bertino, G., Leemans, C.R. and Benazzo, M. (2012) Flap Reconstruction of the Hypopharynx: A Defect Orientated Approach. Acta Otorhinolaryngologica Italica, 32, 288-296.

[2] Wang, W.H., Hwang, T.Z., Chang, C.H. and Lin, Y.C. (2012) Reconstruction of Pharyngeal Defects with a Submental Island Flap after Hypopharyngeal Carcinoma Ablation. Journal for Oto-Rhino-Laryngology, 74, 304-309.

https://doi.org/10.1159/000345100 
[3] Chu, P.Y. and Chang, S.Y. (2009) Reconstruction of the Hypopharynx after Surgical Treatment of Squamous Cell Carcinoma. The Journal of the Chinese Medical Association, 72, 351-355. https://doi.org/10.1016/S1726-4901(09)70386-7

[4] Ki, S.H., Choi, J.H. and Sim, S.H. Reconstructive Trends in Post-Ablation Patients with Esophagus and Hypopharynx Defect. Archives of Craniofacial Surgery, 16, 105-113. https://doi.org/10.7181/acfs.2015.16.3.105

[5] Wu, M.H., Sun, Y.N., Huang, S.T. and Chang, H.Y. (1998) Blood Supply of Esophageal Stumps. Hepato-Gastroenterology, 45, 2055-2059.

[6] Wu, M.H., Wu, H.Y. (2016) Sequential Correction of Caustic Stricture of Trachea and Esophageal Orifice. Clinical Case Reports and Reviews, 2, 484-485.

https://doi.org/10.15761/CCRR.1000253

Submit or recommend next manuscript to SCIRP and we will provide best service for you:

Accepting pre-submission inquiries through Email, Facebook, LinkedIn, Twitter, etc. A wide selection of journals (inclusive of 9 subjects, more than 200 journals)

Providing 24-hour high-quality service

User-friendly online submission system

Fair and swift peer-review system

Efficient typesetting and proofreading procedure

Display of the result of downloads and visits, as well as the number of cited articles

Maximum dissemination of your research work

Submit your manuscript at: http://papersubmission.scirp.org/

Or contact ss@scirp.org 